Eugenia Maksimowicz

DOI $10.15290 / \mathrm{sw} .2016 .16 .23$

Uniwersytet w Białymstoku

Wydział Filologiczny

Instytut Filologii Wschodniosłowiańskiej

tel.+48 857457450

e-mail: maximovitch@interia.pl

\title{
О религиозной лексике современного русского языка в лингвистических исследованиях
}

Ключевые слова: Библия, фразеологизмы библейского происхождения, религиозная лексика, лингвистические исследования.

Библия - книга совершенно исключительная, неисчерпаемая, книга, в которой все сказано как о Боге, так и о человеке. Библия содержит в себе учение религиозного порядка, богооткровенную истину, но и человеческое знание и вся наша умственная деятельность находит в ней пищу. Она легла в основу европейского искусства. Само название заключает в себе и выражает все ее исключительные качества. Слово «библос» у греков уже значило «книга». Для нас же эти три слога «Библия» выражают вершину и совокупность всего написанного. Библия - книга книг. Именно она на протяжении веков далеко превзошла все остальные творения, была и остается самой читаемой книгой в мире.

Учитывая все печатные издания Библии, можно заключить, что общий тираж ее достигает почти миллиарда экземпляров. В переводе она существует почти на семистах языках и диалектах.

Библия как объект исследования представляет интерес для ученых на протяжении долгого времени, поскольку библейские сюжеты «связаны многочисленными нитями не только с языком, но и с разными видами искусства, получая широкое отражение и в изобразительном искусстве, и в музыке, и, конечно, в литературе. Иными словами, бу- 
дучи тесно связанной с европейской христианской культурой, она имеет огромное культурологическое значение» [Дубровина 2001, 98].

Сюжеты, цитаты, крылатые выражения библейского происхождения называются «библеизмами». Они получили достаточно широкое распространение в европейских языках, религией которых является христианство. Библеизмы мы слышим в устной речи, встречаем на газетной полосе, страницах художественных произведений. Но что же следует понимать под библеизмом? В основном в работах российских лингвистов, а также в специальных словарях, под библеизмами традиционно понимаются фразеологические единицы, афоризмы или крылатые фразы из Библии. Е.М. Верещагин под библеизмами понимает «отдельные слова..., устойчивые словосочетания, целые выражения и даже фразы, восходящие по своему происхождению к Библии, которые или заимствованы из Библии, или подверглись семантическому воздействию библейских текстов, в том числе не ассоциируемые с ней в современном языковом сознании» [Верещагин 1993, 97]. Он также отмечает, что библеизмы обладают семантической и стилистической маркированностью (переносным значением, повышенной экспрессивностью, принадлежностью к книжному стилю).

В современном русском языке известно более двухсот устойчивых выражений, так или иначе связанных с текстом Библии. Особенно много фразеологизмов из Нового Завета, прежде всего из Евангелия. Благовещение и Рождество Христово, поклонение волхвов, усекновение главы Иоанна Крестителя, притчи о блудном сыне, об умных и глупьх девах, об исцелении Лазаря и об изгнании бесов, рассказ о насьиении тысяч немногими хлебами, Тайная Вечеря, Иудин почелуй - это далеко не полный перечень тех фрагментов из Священного Писания, которые бытуют в повседневном нашем словоупотреблении как текстовые реминисценции. Быть может, стоит отметить, что определенную роль в этом плане сыграли названия произведений изобразительного искусства, которые все же оставались под своими именами не только на стенах музеев, но подчас и на страницах альбомов и на открытках [Супрун 1995, 23]. Понятно, что такой объем фразеологических единиц составляет пласт, весьма мощный, во всей фразеологической системе русского языка.

К Библии восходит целый ряд фразеологических оборотов, самых разных по значению и структуре. Среди них по лексическому составу и грамматике можно выделить две группы, различные в функционально-стилистическом отношении - 1) обиходные, стилистически нейтральные и книжные, 2) архаические, редкого употребления. 
Первую группу составляют фразеологизмы, не имеющие в своем составе ничего «несовременного и нерусского»: бросить камень, корень зла, голову приклонить, соль земли, не пошевелить пальцем и т.д. Вторая группа состоит из фразеологических оборотов, в которых содержится либо словесная, либо грамматическая «особинка» в виде устаревших слов, морфологических форм или библейских имен собственных: мир дому сему, да минует меня чаша сия, Иов многострадальный, притча во языцех, кесарево кесарю, глас вопиющего в пустыне.

В каждом языке проявляется своеобразное соотношение между фразеологией и текстом Библии.

В современной русистике существует большое количество семантических и семантико-этимологических классификаций фразеологизмов библейского происхождения. Представляют интерес классификации, в которых отражены семантика, этимология и соотношение фразеологической единицы библейского происхождения с текстом первоисточником (Библией). Без опоры на этимологию, связь с текстом Библии и семантику исследуемых единиц становится невозможным выявление семантических особенностей фразеологизмов библейского происхождения в современном русском языке.

Примером такой классификации может послужить работа В.Г. Гака «Особенности библейских фразеологизмов в русском языке» [Гак $1997,3]$, в которой как раз рассматривается соотношение между фразеологизмами и текстом Библии. Исследователь выделяет несколько оппозиций.

1. С точки зрения соотношения с текстом Библии фразеологизмы делятся на две группы: цитатные (контекстуальные) и ситуативные. В первом случае фразеологическая единица представляет собой элемент текста, иной раз несколько измененный, например, выражение камень преткновения встречается в Библии дважды. Во втором случае выражение в соответствующей форме в Библии отсутствует, но оно репрезентирует определенную ситуацию, описание которой в Священном Писании может занимать даже несколько глав. Выражение Ноев ковчег не встречается в Ветхом Завете, оно резюмирует ситуацию, описанную в шестой и седьмой главах Бытия.

Контекстуальные библейские фразеологизмы могут подвергаться различным трансформациям количественного порядка (усечения и добавления) или качественного (замена слов и грамматических форм).

2. В.Г. Гак допускает членение библеизмов по степени их связи с Библией и выделяет первичные и вторичные библейские фразеологизмы. Первичные фразеологизмы непосредственно отражают библейский 
текст или ситуацию, к ним относится подавляющее большинство библейских фразеологизмов. Вторичные библеизмы лишь отдаленно связываются с текстом Библии.

3. Библейские фразеологизмы могут быть непосредственными и опосредованными. Первые восходят непосредственно к Библии, на вторых лежит печать заимствования из других языков или печать отдельных авторов.

Библейские фразеологизмы по семантике можно разделить на имеющие прямое значение и имеющие переносное значение. При сохранении (в целом) формы изменяется значение библейского выражения. Семантическая трансформация способствует фразеологизации библейских словосочетаний. В русском языке переосмыслению может способствовать наличие в библейском фразеологизме церковнославянизмов, первоначальное значение которых забывается. Такое переосмысление произошло с выражением тьма кромешная (Матф. 22: 13), которое поначалу указывало на «внешнюю тьму», куда ввергали грешников, а теперь это выражение обозначает беспросветную темноту.

Рядом с понятием «библейский фразеологизм» стоит понятие сакральной лексики. Слово «сакральный» (восходит к латинскому sacer) обозначает священный, относящийся к религиозному культу и ритуалу, обрядовый ${ }^{1}$.

Сакральную лексику можно разделить на две большие группы: 1) лексика, восходящая непосредственно к библейским текстам ( $a \partial, p a \breve{\text {, }}$ ангел, алтарь, риза и т. д.); 2) слова, не встречающиеся в Священном Писании, но имеющие отношение к религии и церкви (клобук, прихожане, миряне, орарь и т. д.).

В первой группе можно выделить следующие ряды слов.

1. Имена собственные, восходящие к Библии (они достаточно употребительны в языке любой страны, в частности, России, где религией является христианство). В современном русском языке библейские имена входят в основное ядро антропонимики: Марк, Павел, Анна и т. д.;

2. Церковные праздники, часть из которых восходит непосредственно к Библии (Пасха, Рождество, Крещение, Воскресение),

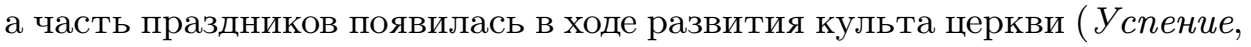
Благовещение, Троища);

3. Обширный ряд составляют слова, используемые в практике отправления религиозных обрядов и в наименовании предметов церковно-

1 Словарь иностранных слов, 1988, Москва, с. 451. 
го обихода: а) церковные принадлежности (ладан, мира, алтарь и т. д.); б) церковные помещения (алтарь, храм, иерковь и т. д.); в) церковные одежды (ряса, саван, риза); г) церковные обряды (молитва, причастие, эпитафия и т. д.).

4. Слова, обозначающие ангелов и их разновидности. Все ангельские чины и имена восходят к Библии (ангел, архангел, серафим, херувим, Рафаил и т. д.);

5. Отвлеченные имена существительные (душа, грех, благодать, спасение и т. д.).

Обратим свое внимание на то, что в современном русском языке наравне с вышеуказанной лексикой присутствуют также слова и выражения, не являющиеся библеизмами. Слова религиозного происхождения или религиозная лексика являются самой обширной группой слов. $\mathrm{K}$ данной группе, по определению А.А. Азарова [Азаров 2002, 10], относятся слова и сочетания слов, возникшие на почве основных религий мира: христианства, мусульманства, буддизма, иудаизма и др. В нее входит лексика, употребляемая в практике отправления религиозных обрядов, в работах по архитектуре культовых сооружений, иконописи, прикладному искусству, истории религии, а также имена святых, богословов, известных религиозных деятелей, названия религиозных праздников, религиозная атрибутика и т. д. Данные слова, по мнению В.В. Кабакчи, служат для наименования так называемых «культуронимов», то есть «языковых единиц, выступающих в качестве элементов обозначения мировой культуры» [Кабакчи 2001, 7], которые в свою очередь подразделяются на полионимы - культуронимы, являющиеся универсалиями в мировой культуре (в религиозной теме к ним относятся такие слова, как религия, вера и т. д., то есть универсальные элементы любой религии); идионимы - культуронимы, специфичные для внутренней культуры данного языка (в русском языке это такие слова, как кулич, иконостас и др.) и ксенонимы - языковые единицы данного языка, используемые в качестве наименований элементов внешних (иноязычных) культур (Будда, Коран, Рамадан и т. д.).

Среди религиозной лексики особое место занимает группа религиозных слов христианского происхождения, то есть слов и выражений, возникших на основе христианской религии и имеющих непосредственное отношение к тексту Священного Писания как ее основе. K ним относятся слова, обозначающие какие-либо реалии, свойственные христианской религии в общем и используемые различными конфессиями в частности. Религиозные слова христианского происхождения по частоте использования и количеству лексических единиц являются одни- 
ми из наиболее широко употребительных в группе слов религиозного происхождения.

Некоторые исследователи наряду с религиозной также выделяют группу церковной лексики. С.В. Булавина [Булавина 2003, 18] под религиозной лексикой понимает единицы, которые называют основные христианские понятия, большая часть которых представлена в Библии. В исследовании С.В. Булавиной религиозная лексика представлена несколькими подгруппами: к первой подгруппе относятся слова, служащие для наименования Верховного Существа и божественных существ. В данную подгруппу входят такие слова, как Бог, Господь, ангел, и устойчивые словосочетания с данными лексемами. К этой же подгруппе относятся вокативные междометия Бог мой, Боже мой и т. д. Ко второй подгруппе относятся слова, служащие для наименования существ, воплощающих зло: бес, дьявол, сатана и др., а также устойчивые сочетания с ними. Третью подгруппу составляют наименования

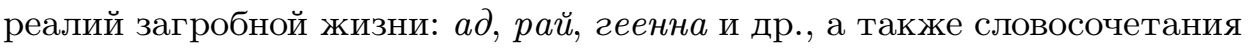
с ними. $\mathrm{K}$ четвертой подгруппе относятся обозначения христианских представлений о человеке: душа, грех, воскреснуть и другие, и словосочетания, связанные с данными словами. По мнению исследователя, религиозная лексика не соотносится с материальной стороной жизни церкви, в этом заключается ее главное отличие от церковной лексики. Церковная лексика, по мнению С.В. Булавиной, представляет значительно большую, по сравнению с предыдущей, группу, в которой также выделяется несколько подгрупп: 1) названия предметов культа, церковной утвари, например, крест, кадило, икона, елей, миро, ладан и т. д., а также устойчивые словосочетания с данными лексемами; 2) названия церковных обычаев, обрядов: крещение, исповедь и др.; 3) названия деталей архитектуры, внутреннего и внешнего устройства храма: алтарь, колокольня и т. п., а также устойчивые словосочетания с данными лексемами; 4) названия подразделений, единиц церковного административного устройства: монастырь, епархия и устойчивые словосочетания с ними.

М.Е. Петухова [Петухова 2003, 24] в своем исследовании, посвященном функциональным особенностям церковной лексики с предметным значением в русском языке, также подразделяет церковную лексику на несколько групп. Данные подгруппы во многом перекликаются с разделением церковной лексики С.В. Булавиной: 1) названия церковных помещений, сооружений, поселений; 2) обозначения предметов церковной утвари, облачения, культовых атрибутов; 3) наименования лиц по отношению к христианской вере: представителей духовных санов, чи- 
нов, сословий, верующих и неверующих людей и иноверцев, монахов и мирян. Однако большинство слов как из группы религиозной, так и церковной лексики, рассматриваемых исследователями (такие как крещение, миро, елей, крест, Господь, ангел, геенна, душа, грех и др.), являются библеизмами, так как зафиксированы в тексте Библии. Подгруппы слов, служащие для наименования лиц по отношению к христианской вере, названия церковных помещений, обозначения церковной утвари, предметов архитектуры, а также единиц церковного административного устройства являются религиозными словами христианского происхождения, которые можно разделить согласно классификации, предложенной В.В. Кабакчи, на полионимы, к которым будут относиться такие слова, как религия, Бог, священник, вера, алтарь, секта, храм, Троииа и т. д.; идионимы, к которым будут относиться культуронимы, специфичные для внутренней культуры русского языка: кулич, масленииа, благовест, старовер и др.

Возвращаясь к библеизмам, не можем не обратиться к работам языковеда Н.В. Климовича, по мнению которого под библеизмами следует понимать фразеологические единиць, как зафиксированные в тексте Священного Писания, так и возникшие на основе библейских сюжетов, а также слова, которые подразделяются на: 1) библеизмь- -имена собственные; 2) библеизмь - топонимы и 3) библеизмы - религиозньле реалии [Климович 2006, 203].

Уже говорилось о том, что библеизмы прочно вошли в наш язык, они продолжают широко и свободно использоваться в настоящее время. На одну из причин «живучести» этих языковых единиц указал А.M. Cелищев: «Их употребление связывается с особой значимостью, выразительностью, с той или иной эмоцией. Это функционально-стилистическое свойство характерно для библейских выражений, заимствованных из текстов Ветхого и Нового Завета и позже переосмысленных, что и сделало их фактами живого языкового употребления. Выражения этого рода, как правило, прочно усвоены и широко употребительны в тех языках, которые прошли стадию “христианской культуры”. Сделавшись неотьемлемой принадлежностью изобразительного речевого репертуара, они пригодны для выражения таких понятий, которым совершенно чужд дух христианской морали или устарелого церковного уклада жизни и мировоззрения. Сознание тех, кто употребляет или слышит библейские выражения в контекстах современной речи, не ассоциируется с их былыми терминологическими значениями, что и обеспечивает им прочное место во фразеологическом фонде современного русского языка» [Селищев 1952, 112]. 
Можем утверждать, что слова и выражения библейского происхождения, будь то библейские фразеологизмы или сакральная и церковная лексика, с их образной системой, яркой выразительностью и глубоким нравственным смыслом отнюдь не являются массой устаревающих языковых единиц. Интерес к библейским выражениям в последнее время не только не угас, но даже усилился. Следствием этого стало увеличение удельного веса библеизмов в новейших словарях и справочниках, в живой повседневной, особенно в публицистической, речи. Взять хотя бы газетные заголовки, типа: «Поиск земли обетованной» [«Литература в школе», 2005, № 6, с. 2]; Тайное и явное [название рубрики в газете «Аргументы и факты»]; «У Путина сначала было слово» [«Литературная Газета», 2007, № 36, с. 1]; «Ищите и обрящете» [«Аргументы и Факты», 2008, № 46, с. 33]; «Не хлебом единьлм. А жирафом вдобавок» [«Культура», 2007, № 27, с. 11]; «Капля в море изображения иных времен и народов» [«Литературная Газета», 2008, № 2, с. 11]; «В Подмосковье подешевела манна небесная» [«Московский комсомолец», 2013, № 26379 от 8 ноября] и т. п.

В последнее время обнаруживается тенденция к злоупотреблению меткими евангельскими фразами, к превращению их в штампы. Это беспокоит, так как зачастую люди употребляют библейские выражения без точного знания об их значении. В данной ситуации как никогда актуальным становится создание словаря библейской фразеологии. Подобные попытки создания словарей предпринимались ни раз, однако на сегодняшний день ни один существующий справочник, по мнению ведущих языковедов, не обладает полнотой и глубиной необходимых сведений. Перед лексикографами встает ряд задач теоретического и практического характера. Предстоит определиться с исходной формой многих библейских фразеологизмов, разграничить варианты и синонимы отдельных оборотов, уточнить, а иногда и частично пересмотреть маркировку библейских выражений, особенно по признаку принадлежности к активному или пассивному лексическому запасу русского языка. Отдельные фразеологические единицы требуют необходимости в уточнении их этимологического происхождения, чтобы разрешить вопрос об их статусе как библеизмов. Думается, что при работе над новым словарем, при отборе материала для него, важным будет разграничить фразеологию от текстовых реминисценций и особенно от нарицательных имен существительных, которые появились на основе библейских образов.

А до тех пор, пока эти проблемы не будут решены адекватно, необходимо всеми возможными способами проводить просветительскую ра- 
боту. И задача эта может быть выполнена путем совместных усилий лингвистов, культурологов и педагогов.

\title{
Литература
}

Азаров А.А., Русско-английский словарь религиозной лексики, Москва, 2002.

Булавина С.В., 2003, Русские устойчивые словосочетания, содержащие черковно-религиозную лексику, Дис. ... канд. филол. наук, Воронеж.

Верещагин Е.М., 1993, Библейская стихия русского языка, "Русская речь" № 1, c. 90-98.

Гак В.Т., 1997, Особенности библейских фразеологизмов в русском языке, "Вопросы языкознания" № 5, с. 3-19.

Дубровина К.Н., 2001, Особенности библейской фразеологии в русском языке, "Филологические науки" № 1, с. 91-98.

Кабакчи В.В., 2001, Практика английского языка межкультурного общения, Санкт-Петербург.

Климович Н.В., 2006, К вопросу об определении библеизма в лингвистике, "Языкознание", Красноярск.

Петухова М.Е., 2003, Функииональные особенности иерковной лексики с предметным значением в русском языке, Дис. ... канд. филолог. наук, Казань.

Селищев А.М., 1951-52, Старославянский язык, Москва.

Словарь иностранных слов, 1988, Москва.

Супрун А.Е., 1995, Текстовые реминисценции как языковое явление, "Вопросы языкознания" № 6, с. 17-29.

\section{ABOUT RELIGIOUS LEXIS OF CONTEMPORARY RUSSIAN LANGUAGE IN LINGUISTIC RESEARCH}

\author{
S U M M A R Y
}

The Bible has attracted the attention of researchers of various specialties for a long time. It is an endless source of themes closely associated with the Christian European culture - its cultural importance is not to undermine.

Expressions taken from the Bible appear in various forms of linguistic communication, in press releases, literary works or oral speech.

In the Russian modern linguistics there are different semantic and semantic etymological proposals to classify the religious lexis and idioms of biblical origin. They all refer to the source text - the Bible, because without these references the semantic analysis of the lexis of the biblical genesis in the modern Russian language would not be possible. 